\title{
Pengaruh Dukungan Suami Pada Perilaku Deteksi Dini Kanker Serviks: Inspeksi Visual Asam Asetat (IVA)
}

\author{
Putri Damayanti*, Putri Permatasari \\ Fakultas Kesehatan Masyarakat Universitas Indonesia \\ *Korespondensi: Putri Damayanti - damayanti647@gmail.com
}

\begin{abstract}
Abstrak
Kanker serviks adalah kanker pada wanita dengan jumlah terbesar keempat di dunia dan terbesar kedua di Indonesia setelah kanker payudara. Kanker serviks merupakan kanker yang terjadi pada daerah organ reproduksi wanita (leher rahim) yang merupakan pintu masuk ke arah rahim yang disebabkan oleh Human Papilloma Virus $(H P V)$. Kanker serviks dapat dicegah melalui pemeriksaan deteksi dini salah satunya dengan metode IVA. Perilaku pemeriksaan IVA pada Wanita Pasangan Usia Subur (WPUS) dipengaruhi oleh beberapa faktor yakni faktor pendukung dan faktor penguat. Dukungan suami merupakan salah satu dari faktor penguat tersebut. Tujuan penelitian untuk mengetahui pengaruh dukungan suami terhadap perilaku WPUS dalam melakukan pemeriksaan IVA. Metode yang digunakan adalah penelusuran literatur. Penelusuran literatur ini dilakukan dengan menelaah hubungan antara dukungan suami dengan pemeriksaan IVA berdasarkan 9 jurnal kesehatan yang dipublikasikan 10 tahun terakhir baik dalam bahasa Indonesia maupun bahasa Inggris yang sesuai dengan kriteria dan didapat melalui berbagai mesin pencari. Hasil dari 9 jurnal yang telah di review 8 diantaranya menjelaskan dukungan suami dapat meningkatkan perilaku pemeriksaan IVA pada WPUS dengan range nilai Odds Ratio berkisar 3,69 sampai 46,6. Dukungan suami memiliki pengaruh positif terhadap perilaku WPUS dalam melakukan pemeriksaan IVA untuk mencegah kanker serviks.
\end{abstract}

Kata Kunci: kanker serviks, IVA, WPUS, dukungan suami

\section{Effect of Husband's Support on Cervical Cancer Early Detection Behavior: Visual Inspection with Acetic Acid (VIA)}

\begin{abstract}
Cervical cancer is cancer in women with the fourth largest number in the world and the second largest in Indonesia after breast cancer. Cervical cancer is cancer that occurs in the area of the female reproductive organs (cervix) which is the entrance to the uterus caused by the Human Papilloma Virus (HPV). Cervical cancer can be prevented through early detection, one of which is the IVA method. The behavior of IVA examinations in women with fertile age couples (WPUS) is influenced by several factors, namely supporting factors and reinforcing factors. Husband's support is one of these reinforcing factors. The research objective was to determine the effect of husband's support on WPUS behavior in conducting IVA examinations. The method used is literature search. This literature search was carried out by examining the relationship between husband's support and IVA examinations based on 9 health journals published in the last 10 years both in Indonesian and English that match the criteria and obtained through various search engines. The results of 9 journals that have been reviewed, 8 of which explain that husband's support can improve the behavior of IVA examinations on WPUS with a range of Odds Ratio values ranging from 3.69 to 46.6. Husband's support has a positive influence on WPUS behavior in performing IVA examinations to prevent cervical cancer.
\end{abstract}

Key Words: cervical cancer, VIA, WFAC, husband's support 
PENDAHULUAN

Kanker serviks menempati posisi keempat kanker pada wanita terbanyak di dunia setelah kanker payudara, kolorektal, dan paru-paru. Pada tahun 2018 diperkiraan 570.000 wanita didiagnosis menderita kanker serviks di seluruh dunia dan sekitar 311.000 wanita meninggal karena penyakit tersebut (1).

Di Indonesia kanker serviks menempati urutan kedua terbanyak setelah kanker Payudara. Pada tahun 2018 kasusnya mencapai 32.469 , atau $17,2 \%$ dari kanker perempuan di Indonesia. angka kematian akibat kanker serviks mencapai 18.279 per tahun yang berarti ada sekitar 50 orang wanita Indonesia meninggal dunia setiap hari akibat kanker serviks (2).

Kanker serviks dapat dicegah melalui pemeriksaan deteksi dini salah satunya dengan metode IVA. Namun, persentase cakupan pemeriksaan deteksi dini kanker serviks (IVA) tahun 2018 hanya sebesar $7,34 \%$ pada wanita pasangan usia subur usia 30-50 tahun, angka tersebut sedikit meningkat di tahun 2019 menjadi 12,2\% $(3,4)$.

Angka tersebut masih jauh dari indikator pencapaian sasaran dalam Rencana Strategis (RENSTRA) Kementerian Kesehatan tahun 2015-2019 yang menargetkan deteksi dini kanker serviks sebesar $50 \%$.
Berbagai penelitian menyebutkan banyak faktor yang mempengaruhi keikutsertaan wanita pasangan usia subur (WPUS) dalam tes IVA salah satu yang paling sering disebutkan adalah peran dukungan suami (5). Semakin besarnya dukungan suami yang diberikan maka semakin baik keikutsertaan wanita pada pasangan usia subur melakukan pemeriksaan IVA (6). Tujuan penulisan ini untuk menganalisis peran dukungan suami terhadap perilaku deteksi dini kanker serviks (IVA) di Indonesia.

\section{METODE}

Metode penelitian ini merupakan penelusuran pustaka (literature review). Penelusuran pustaka menggunakan mesin pencari seperti Google Scholar, Researchgate, Science Direct, Lontar UI serta jurnal elektronik lainnya dengan kata kunci bahasa inggris Husband Support for Early Detection of Cervical Cancer (VIA) serta kata kunci bahasa Indonesia Pengaruh Dukungan Suami Pada Pemeriksaan IVA.

$$
\text { Kriteria inklusi penelitian }
$$
menggunakan jurnal yang dipublikasikan tidak lebih dari 10 tahun terakhir, sedangkan kriteria eksklusi adalah jurnal yang teksnya kurang lengkap dan menjelaskan hubungan diluar pemeriksaan kanker serviks metode IVA. 
Dari total 228 jurnal yang terdiri dari 101 jurnal bahasa inggris dan 127 jurnal bahasa Indonesia yang didapat berdasarkan pencarian sesuai kata kunci, 189 diantaranya belum memenuhi kriteria inklusi lainnya yaitu kesesuaian dengan fokus topik yang diangkat peneliti (tidak relevan). Lalu dari 39 jurnal yang tersisa 28 diantaranya tidak digunakan karena kurangnya kelengkapan data. Sedangkan 2 jurnal lainnya juga tidak dapat digunakan karena keterbatasan akses. Tersisa 9 Jurnal terakhir yang terdiri dari 5 jurnal Bahasa Indonesia dan 4 jurnal Bahasa Inggris.

\section{HASIL}

\section{Kanker Serviks}

Kanker serviks atau karsinoma serviks uteri merupakan keganasan yang ditandai dengan tumbuhnya sel abnormal yang berasal dari sel leher rahim (7). Penelitian menunjukkan bahwa seluruh penyebab utama kanker serviks adalah Human Papilloma Virus (HPV) yang ada pada manusia (8).

Virus HPV dapat ditularkan melalui aktivitas seksual. Beberapa faktor resiko penyebab kanker serviks diantaranya melakukan hubungan seksual di usia muda, karakteristik partner seksual (berulang kali berganti pasangan), merokok, jumlah kelahiran dan faktor resiko lainnya $(7,9)$.

\section{Pencegahan}

\section{1) Pencegahan Primer}

Pencegahan primer dapat dengan melakukan Vaksin HPV untuk mencegah penyakit akibat virus Papilloma yang akan menginfeksi sel epitel di kulit dan membran mukosa bagian serviks, dan menyebabkan keganasan atau kanker (10). Selain itu dengan menunda onset aktivitas seksual dan penggunaan kondom (9).

\section{2) Pencegahan Sekunder}

Skrining merupakan upaya pencegahan sekunder yaitu dengan melakukan pemeriksaan dini atau tes pada orang yang belum menunjukkan gejala penyakit, untuk mendeteksi adanya perubahan prakanker sebelum menyebabkan kanker (9). Terdapat dua metode dalam melakukan skrining yaitu pap smear yang merupakan cara pemeriksaan sitologi untuk mengetahui adanya perubahan pada daerah mulut rahim. Tes pap smear di negara berkembang kurang praktis dilakukan karena membutuhkan pemeriksaan laboratorium dan hasilnya cukup lama untuk diketahui. Metode lainnya sebagai pengganti tes pap smear adalah tes Inspeksi Visual dengan Asam Asetat atau IVA (11).

\section{IVA (Inspeksi Visual Asam Asetat)}

Inspeksi Visual dengan asam asetat (IVA) adalah pemeriksaan leher Rahim 
secara visual menggunakan asam cuka dengan mata telanjang untuk mendeteksi abnormalitas setelah dioleskan asam cuka 3-4 \% (8). Bila daerah tidak normal, maka akan berubah menjadi warna putih yang tegas (acetowhite) yang dapat menjadi tanda kemungkinan serviks memiliki lesi prakanker (12). Metode IVA diperkenalkan pada awal tahun 1925 oleh Hinselman, seiring berjalan waktu dikembangkan oleh WHO sejak tahun 1990 sebagai solusi mengatasi keterbatasan pelaksaan skrining terkait dengan fasilitas dan sumber daya manusia (11).

Akurasi Tes IVA dibeberapa penelitian terbukti cukup baik, sensitivitas untuk mendeteksi lesi derajat tinggi, pelatihan sumber daya manusia untuk melakukan tes IVA lebih cepat dan sederhana dibandingkan dengan cara sitoteknisi. Hasilnya pun lebih cepat untuk diketahui, tidak perlu ada persiapan klien, sehingga dapat diterapkan pada daerah yang sumber dayanya terbatas (11). Di Indonesia, deteksi dini kanker serviks menyasar pada perempuan dengan kelompok usia 20 tahun keatas, prioritas usia 30-50 tahun dengan target 50\% perempuan sampai tahun 2019 . Pada pemeriksaan IVA Indonesia dilakukan pemeriksaan minimal 3 tahun sekali (13).

\section{Dukungan Suami}

Dukungan merupakan sebuah kekuatan yang mengatur perilaku untuk mencapai tujuan dari seseorang yang memiliki hubungan dengan individu (14). Sedangkan dukungan suami merupakan suatu bentuk perwujudan dari sikap perhatian kepada istri dan memiliki andil yang cukup besar dalam menentukan status kesehatannya (15). Friedman (1961) dalam Susanti (2002) menyatakan bahwa sebelum seorang individu mencari pelayanan kesehatan yang professional, biasanya ia akan mencari nasihat dari keluarga dan teman/kerabatnya (16).

Dukungan suami adalah salah satu faktor penguat yang dapat mempengaruhi seseorang dalam berperilaku. Aspek- aspek dukungan dari keluarga dalam hal ini suami diantaranya berupa dukungan emosional, informasi, instrumental, dan penghargaan (17).

Tabel 1. Hasil Temuan Literatur

\begin{tabular}{|c|c|c|c|c|c|}
\hline No & Judul & $\begin{array}{l}\text { Penulis } \\
\text { (Tahun) }\end{array}$ & $\begin{array}{c}\text { Metode \& } \\
\text { Besar Sampel }\end{array}$ & Hasil & Penerbit \\
\hline 1. & $\begin{array}{lr}\text { Hubungan } & \text { Dukungan } \\
\text { Suami Dan Dukungan } \\
\text { Petugas } & \text { Kesehatan } \\
\text { Terhadap } & \text { Perilaku } \\
\text { Pemeriksaan } & \text { IVA Di }\end{array}$ & $\begin{array}{c}\text { Umami Desi } \\
\text { Aulia, } 2019 \\
\text { (18) }\end{array}$ & $\begin{array}{c}\text { Cross } \\
\text { Sectional, } \\
\text { dengan } 57 \\
\text { responden }\end{array}$ & $\begin{array}{l}\text { Terdapat hubungan } \\
\text { dukungan suami ditunjukan } \\
\text { hasil uji chi square pada } \\
\text { tingkat kepercayaan } 95 \% \text {, } \\
\text { didapatkan nilai p } \\
\text { value }=0,016 \text { dengan nilai }\end{array}$ & $\begin{array}{l}\text { Journal Of } \\
\text { Midwifery. } \\
\text { Fakultas Ilmu } \\
\text { Kesehatan } \\
\text { Universitas }\end{array}$ \\
\hline
\end{tabular}




\begin{tabular}{ll}
\hline No & \multicolumn{1}{c}{ Judul } \\
\hline & $\begin{array}{l}\text { Puskesmas } \\
\text { Serai }\end{array}$ \\
& \\
& \\
2. Paktang & \\
& \\
Berhubungan dengan \\
Perilaku WUS dalam \\
Deteksi Dini Kanker \\
Leher Rahim Metode \\
IVA di Wilayah \\
Puskesmas Prembun \\
Kabupaten Kebumen \\
Tahun 2012
\end{tabular}

3. Husband Support and Health Workers Support on Iva Examination Practices In Fertile Age Women

4. Factors affecting behaviors of cervical cancer screening using VIA (Visual Inspection with Acetic Acid) method on women in Srengseng Sawah Jakarta Indonesia

5. Factors Associated with Visual Inspection Acetic Acid Examination at the Independent Medical

\section{Yuliwati,}

2012 (19)

Kurniati P. $\mathrm{T}, 2019(20)$

Cross

Sectional, dengan 57 responden Cross
Sectional,
dengan 212
responden

Nurhasanah dan Afiyanti. Y, 2016

$$
\begin{aligned}
& \text { Kabuhung, } \\
& \text { E. I dan }
\end{aligned}
$$

Hakim A.R, 2019 (22) responden responden

dengan
Hasil

Odds Ratio $\quad(\mathrm{OR})=4,190$ yang bermakna istri yang memperoleh dukungan suami memiliki resiko 4,190 kali lebih besar untuk melakukan IVA daripada yang tidak memperoleh dukungan suami

Ada hubungan antara dukungan suami dengan perilaku WUS dalam melakukan IVA. Hasil uji statsistik diperoleh nilai $p$ value $=0,0001$ dan nilai prevalens rasio (PR/OR) sebesar 5,587 yang berarti istri yang didukung suami beresiko 5,587 kali lebih besar untuk periksa IVA dibandingan dengan yang tidak didukung suami

Terdapat hubungan antara dukungan suami dengan keikutsertaan skrining IVA test pada Pasangan Usia Subur, ditunjukkan nilai $\mathrm{p}$ value sebesar 0,016 dengan nilai $\mathrm{OR}=4,19$ yang menunjukkan istri yang memperoleh dukungan suami beresiko 4,19 kali lebih besar untuk melakukan IVA daripada yang tidak memperoleh dukungan suami

Cross Berdasarkan uji statistik Sectional, diketahui bahwa suami dengan 176 yang mendukung (tidak menghambat) istri memiliki hubungan dengan perilaku istri dalam pemeriksaan IVA ditunjukkan dengan nilai $\mathrm{p}$ value $=0,028$ dengan nilai $\mathrm{OR}=5,18$ yang berarti adanya dukungan suami meningkatkan resiko 5,18 kali perilaku istri untuk periksa IVA

Ada hubungan antara dukungan suami terhadap perilaku pemeriksaan IVA pada pada WPUS ditunjukkan oleh nilai $p$ value $=0,045$ dengan nilai

Penerbit

Dehasen

Bengkulu

Skripsi.

Fakultas

Kesehatan

Masyrakat

Universitas

Indonesia

Journal of

Research in

Public Health

Sciences.

UI Proceedings on Health and Medicine

European

Union Digital

Library NSpurposive sampling 


\begin{tabular}{l} 
No Judul \\
\hline $\begin{array}{l}\text { Center of Doctor } \\
\text { Aloysius }\end{array}$ \\
The Influence of \\
Personal Factor, \\
Husband's Support, \\
Health Workers and \\
Peers toward the Use \\
of IVA Screening \\
among Women of \\
Reproductive Age in \\
the Regency of \\
Karanganyar \\
Faktor \\
Berhubungan dengan \\
Deteksi Dini Kanker \\
Serviks Metode IVA \\
di Puskesmas Kota \\
Padang
\end{tabular}

8. Analisis Faktor Yang Mempengaruhi

Perilaku Ibu Dalam Pelaksanaan Tes IVA di Wilayah Kerja Puskesmas

Hutarakyat

Kabupaten Dairi

Tahun 2019

9. Path Analysis on the Determinants of Visual Inspection Acetic Acid Utilization on Early Detection of Cervical Cancer: Application of Health Belief Model Theory

$\begin{array}{cc}\begin{array}{c}\text { Penulis } \\ \text { (Tahun) }\end{array} & \begin{array}{c}\text { Metode \& } \\ \text { Besar Sampel }\end{array}\end{array}$

OR=7 yang berarti istri
yang memperoleh
dukungan suami beresiko 7
kali lebih besar untuk
periksa IVA daripada yang
tidak didukung suami.

Wakhidah

M.S et al,

2017 (23)

Cross

Sectional,

dengan 150

responden

Fauza. M et al, 2019 (24)

Explanatory
research
dengan
pendekatan
Cross
sectional, 110
responden

Tidak ada hubungan antara dukungan suami dengan skrining IVA pada WPUS ditunjukkan dari hasil uji didapatkan nilai $p$ value $=0,081$ dengan nilai $\mathrm{OR}=2,02$. yang bermakna dukungan suami hanya meningkatkan resiko 2,02 kali perilaku istri untuk periksa IVA

Hasil uji multivariate menunjukkan dukungan suami merupakan variabel paling berpengaruh terhadap keikutsertaan WPUS dalam tes IVA dengan nilai $p$ value $=0,0001$ dan POR sebesar 46,6 yang bermakna adanya dukungan suami meningkatkan resiko 46,4 kali perilaku istri untuk melakukan IVA.

Manihuruk, S.A 2019

Cross Sectional, dengan 96 responden

Hasil dari penelitian didapatkan nilai $p$ value $=0,042$ yang berarti ada hubungan antara dukungan suami dengan perilaku WPUS pada tes IVA dengan nilai $\mathrm{OR}=17,0$ menunjukkan istri yang memiliki dukungan suami beresiko 17,0 kali untuk periksa IVA dibandingkan dengan yang tidak didukung

Sunarta E.A et al, 2019
Case Control, dengan 200 responden
Ada hubungan antara WPUS melakukan tes IVA dengan dukungan suami. Hasil uji statsistik diperoleh nilai $\mathrm{p}$ value $=0,001 \mathrm{dan}$ $\mathrm{OR}=3,69$ yang berarti istri yang memiliki dukungan suami beresiko 3,69 kali lebih besar untuk periksa IVA daripada yang tidak didukung suami.
Journal of Health

Promotion and Behavior.

Faculty of Medicine, Sebelas Maret University, Surakarta

Jurnal Promosi Kesehatan Indonesia. FKM UNAND

Tesis. Fakultas Kesehatan Masyarakat Institut Kesehatan Helvetia Medan

Journal of Health

Promotion and Behavior. Universitas Sebelas Maret 


\section{PEMBAHASAN}

Berdasarkan hasil kajian pustaka dari 9 jurnal yang memenuhi kriteria, terdapat 8 jurnal yang menyatakan bahwa ada hubungan bermakna antara peran dukungan suami dengan perilaku deteksi dini kanker serviks metode inspeksi visual asam asetat (IVA). Umumnya wanita usia subur yang besedia melakukan tes IVA mendapatkan dan memiliki dukungan dari suaminya. Hasil penelitian Umami (2019) menunjukkan bahwa dukungan suami berhubungan dengan perilaku pemeriksaan IVA oleh wanita usia subur ( $p$ value $=0,016$; $\mathrm{OR}=4,190$ ) yang berarti wanita usia subur yang memiliki dukungan suami yang buruk memiliki resiko 4,190 kali untuk tidak melakukan pemeriksaan IVA dibandingkan dengan yang mempunyai dukungan suami yang baik (18).

Sejalan dengan hasil peneltian Nurhasan dan Afiyanti (2019) yang menjelaskan bahwa adanya dukungan suami turut mempengaruhi keikutsertaan istri dalam pemeriksaan IVA (p value $=0,028 ; \mathrm{OR}=5,18)$. Artinya, dukungan yang diberikan suami meningkatkan peluang keikutsertaan wanita usia subur untuk melakukan pemeriksaan IVA sebanyak 5,18 kali. Hasil akhir dari penelitiannya menunjukkan terdapat hubungan yang signifikan antara dukungan suami dengan keikutsertaan WPUS dalam tes IVA dengan nilai $\mathrm{p}$ value $=0,0001$ dan OR sebesar 46,6 yang artinya WPUS yang mendapatkan dukungan suami mempunyai kemungkinan 46 kali melakukan tes IVA dibandingkan dengan WPUS yang tidak didukung suami untuk tes IVA. Dukungan suami pada dasarnya merupakan salah satu faktor penguat yang dapat mempengaruhi seseorang dalam berperilaku. Aspek- aspek dukungan dari keluarga dalam hal ini suami diantaranya berupa dukungan emosional, informasi, instrumental, dan penghargaan $(17,21)$.

Terdapat 1 jurnal dari 9 jurnal yang menyatakan bahwa tidak ada hubungan antara dukungan suami dengan perilaku deteksi dini kanker serviks metode inspeksi visual asam asetat (IVA). Dalam penelitian Wakhidah, et al (2017) didapatkan hasil uji chi-square bahwa dukungan suami dengan nilai $p$ value $=0,081$ dan $O R=2,02$ memiliki arti tidak ada pengaruh antara dukungan suami terhadap perilaku WPUS dalam melakukan tes IVA. Hal tersebut menunjukkan bahwa dukungan suami belum menjamin istri atau WPUS untuk melakukan tes IVA. Tidak hanya dukungan suami, penelitian tersebut juga menjelaskan faktor penguat lainnya yakni dukungan petugas kesehatan ( $p$ value $=0,056$; $\mathrm{OR}=2,04)$, kerentanan ( $\mathrm{p}$ value $=0,08$; $\mathrm{OR}=1,91)$ serta hambatan yang dirasakan ( $\mathrm{p}$ value $=0,058 ; \quad \mathrm{OR}=1,40$ ). Semua hasil tersebut menunjukkan tidak ada yang 
mempengaruhi WPUS dalam melakukan tes IVA (23).

Menurut Yustisianti

menyatakan bahwa dukungan suami adalah salah satu wujud dari faktor penguat (reinforcing factors) dimana semakin besar dukungan yang didapatkan istri untuk melakukan pemeriksaan IVA maka akan terjadi perubahan perilaku istri untuk melakukan IVA test secara berkala (27). Hasil penelitian Fauza dkk (2019) juga menunjukkan bahwa sebesar 83,8\% WPUS yang tidak pernah melakukan pemeriksaan IVA tidak mendapat dukungan dari suami untuk melakukannya. Sebagian besar suami tidak memberikan dukungan kepada WPUS untuk mengikuti deteksi dini kanker serviks melalui tes IVA $(67,3 \%)(24)$.

\section{KESIMPULAN}

Tes IVA merupakan pencegahan sekunder terhadap kanker serviks dengan tingkat akurasi baik dan praktis yang dapat digunakan sebagai tes pengganti pap smear. Keikutsertaan tes IVA pada wanita pasangan usia subur (WPUS) turut ditentukan oleh faktor penguat seperti adanya dukungan suami.

Hasil penelitian menunjukkan bukti yang variatif dengan nilai Odds Ratio (OR) berkisar 3,69 sampai 46,6 mengenai hubungan antara dukungan suami dengan pemeriksaan IVA. Penelitian kuantitatif telah banyak memberikan hasil bahwa dukungan suami memberikan peluang keikutsertaan tes IVA oleh WUS di Indonesia.

Berdasarkan hasil tersebut maka perlu kiranya ada upaya peningkatan kegiatan pendidikan dan promosi kesehatan yang tidak hanya diberikan kepada ibu atau istri melainkan juga kepada suami sebagai salah satu pendorong perilaku IVA test untuk medeteksi kanker Serviks. Suami diharapkan juga dapat terbuka terhadap informasi tersebut dan bersedia mendorong serta mendampingi pasangannya untuk saling memperhatikan kesehatan reproduksinya serta meningkatkan partisipasi dalam pemeriksaan IVA untuk mencegah terjadinya kanker serviks.

\section{DAFTAR PUSTAKA}

1. World Health Organization (WHO). Cervical cancer [Internet]. 2018. Available from: https://www.who.int/healthtopics/cervical-cancer\#tab=tab_1

2. GLOBOCAN. Cancer today [Internet]. GLOBOCAN. 2018 [cited 2019 Oct 19]. Available from: http://gco.iarc.fr/today/home

3. Kementerian Kesehatan Republik Indonesia. Profil Kesehatan Indonesia Tahun 2018. Jakarta: Kementerian Kesehatan Republik Indonesia; 2019. 
4. Kementerian Kesehatan RI. Profil Kesehatan Indonesia 2017. Profil Kesehat Indones 2017. 2018;100.

5. Kusumaningrum T. Men's Participation to Support Early Detection of Cervical Cancer in Indonesia: A Literature Review. In Atlantis Press; 2017. p. 171-3.

6. Wildayanti. Hubungan Dukungan Suami Dengan Keikutsertaan Pemeriksaan Inspeksi Visual Asam Asetat (IVA) Pada Pus Di Puskesmas Kotagede 2 Kota Yogyakarta . [Yogyakarta]: Universitas 'Aisyiyah Yogyakarta; 2018.

7. Komite Penanggulangan Kanker Nasional. Pedoman Nasional Pelayanan Kedokteran: Kanker Serviks. Jakarta: Kementerian Kesehatan Republik Indonesia; 2017.

8. Kementrian Kesehatan Republik Indonesia. Buku Saku Pencegahan Kanker Leher Rahim \& Kanker Payudara. Jakarta: Kementerian Kesehatan Republik Indonesia; 2009.

9. Rasjidi I. Epidemiologi Kanker Serviks. Indones J Cancer. 2009;3(3):103-8.

10. Fadhila SR. Sekilas tentang Vaksin HPV [Internet]. IDAI. 2017. Available from:

https://www.idai.or.id/artikel/klinik/i munisasi/sekilas-tentang-vaksin-hpv
11. Aprilla GG, Purwanana R. Perilaku Deteksi Dini Kanker Serviks Melalui Metode Pemeriksaan Inspeksi Visual Asam Asetat (IVA) pada Mahasiswa Magister FKM UI Menurut Teori Proceede - Preceede Tahun 2019. Yars Med J. 2020;27(3):095-120.

12. Kementrian Kesehatan RI. Panduan Program Nasional Gerakan Pencegahan Dan Deteksi Dini Kanker Kanker Leher Rahim Dan Kanker Payudara [Internet]. Jakarta: Kementrian Kesehatan RI; 2015. Available from: http://p2ptm.kemkes.go.id/uploads/20 16/10/Panduan-Program-NasionalGerakan-Pencegahan-dan-DeteksiDini-Kanker-Kanker-Leher-Rahimdan-Kanker-Payudara-21-April2015.pdf

13. Wantini NA, Indrayani N. Early Detection of Cervical Cancer with Visual Inspection using Acetic Acid (VIA). J Ners dan Kebidanan (Journal Ners Midwifery). 2019;6(1):027-34.

14. Astuti KT, Sulastri. Hubungan Antara Dukungan Suami Dengan Pengetahuan Penggunaan Metode Operasi Wanita (Mow) Di Desa Pentur Kecamatan Simo Kabupaten Boyolali. [Surakarta]: Universitas Muhammadiyah Surakarta; 2016.

15. Mulyanti L, Mudrikatun, Sawitry. Hubungan Dukungan Suami Pada Ibu 
Hamil Dengan Kunjungan Anc Di Rumah Bersalin Bhakti Ibi Jl. Sendangguwo Baru V No 44c Kota Semarang. J Kebidanan. 2013;2(1).

16. Susanti NN. Analisis Keterlambatan Pasien Kanker Serviks Dalam Memeriksakan Diri di Rumah Sakit Umum Pusat Dr. Cipto Mangunkusumo Jakarta. Universitas Indonesia; 2002.

17. Friedman MM. Buku Ajar Keperawatan Keluarga : Riset, Teori, \& Praktik. Jakarta: EGC; 2010.

18. Umami DA. Hubungan Dukungan Suami dan Dukungan Petugas Kesehatan Terhadap Perilaku Pemeriksaan IVA di Puskesmas Padang Serai. J Midwifery. 2019;7(2):9-18.

19. Yuliwati. Faktor-Faktor yang Berhubungan dengan Perilaku WUS dalam Deteksi Dini Kanker Leher Rahim Metode IVA di wilayah Puskesmas Prembun Kabupaten Kebumen Tahun 2012. Univeristas Indonesia; 2012.

20. Kurniati PT. Husband Support And Health Workers Support On Iva Examination Practices In Fertile Age Women. J Res PUBLIC Heal Sci. 2018;1(1):14-28.

21. Nurhasanah N, Afiyanti Y. Factors affecting behaviors of cervical cancer screening using VIA (Visual
Inspection with Acetic Acid) method on women in Srengseng Sawah Jakarta Indonesia. In: UI Proceedings on Health and Medicine. Depok; 2017.

22. Kabuhung EI, Hakim HAR. Factors Associated with Visual Inspection Acetic Acid Examination at the Independent Medical Center of Doctor Aloysius. In: NS-UNISM. Banjamasin: EAI; 2019.

23. Wakhidah MS, Budihastuti UR, Dewi YLR. The Influence of Personal Factor, Husband's support, Health Workers and Peers toward the Use of IVA Screening among Women of Reproductive Age in the Regency of Karanganyar. J Heal Promot Behav. 2017;02(02):124-37.

24. Aprianti A, Fauza M, Azrimaidalisa A. Faktor yang Berhubungan dengan Deteksi Dini Kanker Serviks Metode IVA di Puskesmas Kota Padang. J Promosi Kesehat Indones. 2018;14(1):68.

25. Manihuruk SA, Asriwati, Sibero JT. Analisis Faktor Yang Mempengaruhi Perilaku Ibu Dalam Pelaksanaan Tes Iva Di Wilayah Kerja Puskesmas Hutarakyat Kabupaten Dairi Tahun 2019. JKM (Jurnal Kesehat Masyarakat) Cendekia Utama. 2021;8(2):238-60.

26. Sunarta EA, Sulaeman ES, Budihastuti UR. Path Analysis on the Determinants 
of Visual Inspection Acetic Acid

Utilization on Early Detection of

Cervical Cancer: Application of Health

Belief Model Theory. J Heal Promot

Behav. 2019;4(1):32-42.

27. Yustisianti EN, Suryaningsih EK.

Hubungan Dukungan Suami dengan

Perilaku Wanita Usia Subur (WUS)

Melakukan Pemeriksaan Inspeksi

Visual Asam Asetat (IVA) di

Puskesmas Kasihan I. [Yogyakarta]:

Universitas 'Aisyiyah Yogyakarta;

2017. 